\title{
MOŻLIWOŚCI NOWEJ INTERPRETACJI DOGMATÓW W ŚWIETLE KONSTYTUCJI SOBOROWEJ „DEI VERBUM““
}

Temat powyższy potraktuję z pozycji biblisty. Ale dlaczego biblista ma się zająć komentarzem tej Konstytucji? Przynajmniej dwie racje skłaniają do tego. Zacznijmy od mniej oczywistej. Hasło nowej interpretacji dogmatów brzmi może trochę niepokojąco, trochę sensacyjnie. U jednych wywołuje ono przykry lęk o to, by przez nową interpretację nie uronić niczego $\mathrm{z}$ depozytu Objawienia. $U$ innych zaś wywołuje dreszcz ciekawości w zetknięciu z czymś świeżym, bardziej ekspresyjnym, czymś, co się da łatwiej wyzyskać po apostolsku. Obu tych spontanicznych reakcji na ogół nie doznaje ktoś zajmujący się zawodowo Pismem św. A to przede wszystkim dlatego, że dla biblisty reinterpretacja prawdy wcale nie jest zjawiskiem nowym. Jej bowiem proces zaczyna się już na kartach samejże Biblii, ilekroć autorzy poszczególnych ksiąg późniejszych na nowo odczytują i swoiście interpretują dane ksiąg dawniejszych. Żeby użyć przykładu najbardziej rzucającego się w oczy: autor Księgi Mądrości dla swojej tezy naczelnej umiejętnie posługuje się danymi Pięcioksięgu, zaczynając od opisu rajskiego upadku, a kończąc na dziejach Wyjścia z Egiptu. W jeszcze większym stopniu apostołowie Jezusa Chrystusa i cały pierwotny Kościół stosuje taką relecture wobec wielu tekstów ST, zwłaszcza mesjańskich, dając im nową interpretację odpowiednią do przeżytych faktów paschalnych. Proces więc reinterpretacji wydaje się zupełnie zrozumiałym bibliście, który wie, że dzieje zbawienia jeszcze się nie zamknęły. Dla niego więc dzisiejsza cogitatio fidei jest postulatem analogicznym do hasła Ecclesia semper reformanda.

Racja zaś druga, która uzasadnia zajęcie się tą Konstytucją przez biblistę, to fakt, że od czasów wielkich soborów starożytności chrześcijańskiej II Sobór Watykański był bodaj najbardziej biblijnym, gdy cho- 
dzi o swą inspirację i argumentowanie cytatami czy przynajmniej aluzjami z Pisma św. Co więcej Sobór ten określa wzajemny stosunek objawienia biblijnego, Tradycji i urzędu nauczycielskiego Kościoła oraz stosunek teologii do Pisma św. Uczynił zaś to tak wyraźnie i normatywnie, że teraz po Soborze już nie można powtórzyć zarzutu, jaki Karl Barth kiedyś postawił teologom katolickim, iż tam umieszczają Denzingera, gdzie powinno być Pismo św. Zalecenie $z$ rozdziału końcowego naszej Konstytucji brzmi: „Niech studium Pisma św. będzie jakby duszą teologii świętej" (KO 24, 41).

Mam więc tu szkicowo odpowiedzieć na pytanie, czego w zakresie nowej interpretacji dogmatów można oczekiwać od łatwo dostrzegalnego dziś zjawiska ,wiosny biblijnej” (Kard. König), ale w myśl nowych wskazań omawianej Konstytucji. Z bogatych zatem osiągnięć współczesnej biblistyki weźmiemy tu pod uwagę tylko te, które służą procesowi nowej interpretacji prawd wiary. A skoro może ona mieć wiele założeń i rozmaite cele, z Konstytucji ,Dei Verbum” uwzględnimy tylko to, co stanowi przysłowiowe ,zielone światło" dla mozolnego biblijnego ressourcement. Powrót do tego źródła jest koniecznym wstępnym warunkiem reinterpretacji. Inaczej może ona łatwo się stać tylko negacją lub nieodpowiedzialnym — jak to określił mocno J. Coppens — „karnawałem teologicznym".

Metodycznie wyjdziemy z komentarza do tekstu Konstytucji. Jak wiadomo, tekst ten jest kompromisem, wypadkową czy syntezą dwóch tendencji ścierających się podczas Soboru: konserwatywnej i postępowej, obydwu uprawnionych i po swojemu słusznych. Tę drugą, postępową, wywołały głównie dwie potrzeby: ad extra - potrzeba dialogu ze światem współczesnym, ad intra - potrzeba nowego, bardziej niż dotąd zrozumiałego kerygmatu, zwłaszcza w ramach odrodzonej liturgii, która obficiej niż dotąd korzysta ze skarbca Pisma św. Sledzić więc będziemy w tekście Konstytucji kontrast iście ewangelijny: nova et vetera.

Najłatwiej byłoby zacząć od wyszukania w konkordancji do dokumentów soborowych terminów, które nas interesują. Tymczasem tu nas czeka pierwsza trudność: brak zupełny tych terminów. I tak słowo dogma nie pada ani razu. Nie ma też nigdy liczby mnogiej veritates w tym znaczeniu. Pojawiają się tylko ,doctrinae”, i to tylko w kontekście mówiącym o ST. Darmo też szukać w tekście najważniejszego słowa ,interpretatio”. Zachodzi ono tylko w tytule rozdziału III: „De Sacrae Scripturae divina inspiratione et de eius intepretatione". Sam czasownik ,interpretari" dwukrotnie w Konstytucji określa funkcję Magisterium Kościoła względem Pisma św. (KO 10, 57; 12, 37 n), w trzecim zaś wypadku chodzi o ogólną zasadę hermeneutyki, ale znowu biblijnej (KO 12, 32). Rzeczownikiem zaś ,,interpres” nasz dokument okre- 
śla stale egzegetę, posługując się nim trzykrotnie w $\S 12$. Wynik ten, z pozoru całkiem negatywny, ubocznie wskazuje jednak na doniosłość źródła, jakim jest pisane Słowo Boże i tym samym uzasadnia hasło biblijnego ressourcement.

Wobec tego nie pozostaje nam nic innego jak szukać w tekście Konstytucji owych ,zielonych świateł” dla nowej interpretacji w tych punktach, gdzie występują nova w kontraście do vetera. Dodatkową zaś pomocą będzie dla nas swoisty argument ex silentio, mianowicie świadome, jak wynika $\mathrm{z}$,Relationes”, przemilczenia w naszym dokumencie spraw żywo dyskutowanych przed Soborem i podczas jego obrad. Te przemilczenia stwierdzają pośrednio, że badania w tym kierunku są nadal aktualne ${ }^{1}$.

Zaczniemy więc od wydobycia na jaw interesujących nas zasad, a w drugiej części podamy przykłady ich zastosowania do nowej interpretacji dogmatów.

\section{ZASADY}

Pierwszą najogólniejszą zasadą jest w naszym dokumencie wyraźnie różniąca się od ujęcia przez I Sobór Watykański ${ }^{2}$ sprawa samej wi a r y. Jej koncepcja jest wyraźnie bardziej biblijna, tzn. bardziej dynamiczna i personalistyczna. Wystarczy tu przytoczyć ostatnie zdanie z $\S 5$ : , aby zaś coraz głębsze było zrozumienie objawienia, tenże Duch Swięty darami swymi stale wiarę udoskonala" oraz ostatnie zdanie z $\S 8$ : ,...Duch Swięty, przez którego żywy głos Ewangelii rozbrzmiewa w Kościele, a przez Kościół w świecie, wprowadza wiernych we wszelką prawdę oraz sprawia, że słowo Chrystusowe obficie w nich mieszka". A zatem jakby hasłem staje się profundior revelationis intelligentia. Komentatorzy Konstytucji podkreślają, że jego sens staje się szczególnie dobitny w zestawieniu z odpowiednią "Relatio" zgłoszoną do tzw. tekstu E w lipcu 1964: ,ita innuitur continuitas inter primum assensum et progressum, non solum pro singulis fidelibus, sed etiam pro communitate". Innymi słowy - we wspólnocie wierzących doskonali się pod wpływem Ducha Świętego głębsze ujęcie raz podanego objawienia ${ }^{3}$.

Nowe w naszym dokumencie ujęcie Tradycji, która w praktyce jest synonimem wiary Kościoła, mówi wyraźnie o jej postępie i wzroście. Trzy czynniki tego procesu wylicza $\S$ 8: 1. kontemplacja i dociekanie wiernych, 2. głębokie doświadczalne poznanie spraw duchowych, 3. nauczanie biskupów; kończąc stwierdzeniem: „Kościół z biegiem wieków

1 Tego zdania jest skądinąd krytycznie usposobiony do osiągnięć tego dokumentu soborowego O. Loretz, Die hermeneutische Grundsätze des II. Vatikanischen Konzils, w: Die hermeneutische Frage in der Theologie, Freiburg i/Br 1968, 467-479.

2 Konstytucja „De fide catholica”: DBU 1769-1791; DS 3004-3010; BrevFid 48-50.

3 Por. J. Ratzinger, LThK. Das II Vatikanische Konzil, 2, 513 n. 
dąży stale do pełni prawdy Bożej, aż wypełnią się w nim słowa Boże" (KO 8, 28-34). W ostatnim urywku, mimo że soborowi redaktorzy tekstu nie uwydatnili tego formalnym odsyłaczem, łatwo można dosłyszeć echo wielkoczwartkowych zapowiedzi o posłannictwie Ducha $\mathrm{Pa}-$ rakleta: „On was wszystkiego nauczy i przypomni wam wszystko, co Ja wam powiedziałem" ( $J$ 14, 26). "...On będzie świadczył o Mnie, ale wy też świadczycie, bo 'jesteście ze Mną od początku” (J 15, 26). ,...On, Duch prawdy, doprowadzi was do całej prawdy" (J 16, 13).

Z powyższych określeń wynika, że szukanie współczesnego, zrozumiałego -- oczywiście na tyle, na ile samo misterium dopuszcza - wyrazu dla objawienia jest z pewnością uprawnione. Co więcej, należy do zadań tych ludzi, którzy wiarą żyją i mają ją głosić innym. Słuszną więc wydaje się być następująca charakterystyka zdrowych dążeń postępowych w teologii: „Główna troska - to, wychodząc z naszej sytuacji historycznej i z naszej dzisiejszej kultury, zrozumieć słowo Boże dzisiaj do nas skierowane poprzez Pismo św. i poprzez jego interpretację daną przez Tradycję i magisterium Kościoła" " . Nacisk tu położony na obecny adres „listu Boga do ludzi” odpowiada w pełni intencjom Konstytucji. On też stanowi legitymację dla poczynań reinterpretacyjnych.

Prawda Pisma św. stanęła w naszym dokumencie w nowym świetle. Zaniechano dotychczasowego określenia inerrantia zamieniając na ,veritas ...nostrae salutis causa consignata" (KO 11, 13). Ta zamiana - wynik długich dyskusji i metamorfoz tekstu — obchodzi głównie biblistów. Kończy bowiem okres uciążliwych zmagań z pseudoproblemami powstałymi w wyniku rozbieżności danych biblijnych $\mathrm{z}$ osiągnięciami nauk świeckich, empirycznych, zmagań w rodzaju sprawy Galileusza. Z tym określeniem kończy się biblijny konkordyzm, kończy się sens upartych apologii litery Pisma wobec zarzutów ze strony nauk historycznych. Aktualny profesor introdukcji biblijnej na Papieskim Instytucie Biblijnym w Rzymie ujął dowcipnie tę zmianę sytuacji, jaką sankcjonuje nasz dokument: „O ile, lat temu mnie więcej sześćdziesiąt teologowie walczyli, by bronić Pismo św., teraz wysilają się, by je rozumieć" 5. Ta zmiana nacisku na prawdę raczej niż na wolność od błędu jest też ważna dla naszego zagadnienia, precyzując, o jaką prawdę nam chodzi, mianowicie o tę, która dotyczy zbawienia. „Nie jest to prawda w sensie greckim, prawda historyczna jako taka: chodzi o prawdę w sensie biblijnym i tra-

${ }^{4}, \ldots .$. à l'heure actuelle, le souci dominant de la dogmatique, au moins chez ses meilleurs représentants, est de comprendre, à partir de notre situation historique et de notre culture présente, la Parole que Dieu nous adresse aujourd'hui à travers l'Ecriture et à travers son interprétation par la Tradition et le magistère". H. Bouillard, Exégèse, herméneutique et théologie - problèmes de méthode, w: Exégèse et herméneutique (praca zbiorowa pod redakcją X. Léon-Dufour), Paris 1971, 277.

5 L. Alonso Schökel, La parola ispirata, Brescia 1967, 302. 
dycyjnym, tj. o treść Bożego Objawienia, która zawsze w jakiś sposób odnosi się do zbawienia ludzi" ${ }^{6}$. Tą prawdą jest sam Boski Logos, odwieczna Mądrość w swojej synkatábasis do ludzkich słów - sens obu Testamentów, jak go widzieli Ojcowie Kościoła, a mówi o tym dopiero $\S 13$ Konstytucji. To ujęcie wprowadza nas w nową aurę, daje szerzyznę i głębię, jakiej nie można było nawet przeczuć w dawnym jawnie negatywnym sformułowaniu: in-errantia. Nową pełnię treści można by zilustrować następującym porównaniem. Zdziwiłby się każdy dogmatyk, jeśliby mu powiedziano, iż głównym następstwem Wcielenia była wolność Chrystusa od najmniejszego grzechu. Z pewnością była ona skutkiem, ale przecież nie najważniejszym. A do niedawna nas nie dziwiło to, że jako skutek natchnienia biblijnego przyjmowano głównie, jeśli nie wyłącznie, wolność od błędu ${ }^{7}$. Tymczasem to nowe ujęcie prawdy jest echem wielu określeń Czwartej Ewangelii w rodzaju: „łaska i prawda przyszły przez Jezusa Chrystusa” (J 1, 17), „Poznacie prawdę, a prawda was wyzwoli” $(8,32)$, „Ja jestem drogą i prawdą, i życiem” $(14,6)$. $\mathrm{Z}$ drugiej strony nie ma konieczności, jak postuluje kilku autorów ${ }^{8}$, utożsamiania go $\mathrm{z}$ treścią hebrajskiej, starotestamentalnej 'emet. Nic bowiem nie wskazuje taką intencję u Ojców soborowych. Tę koncepcję warto włączyć do ogólnego pojęcia prawdy objawionej, ale nie ma potrzeby do niej się ograniczać.

Nowe to ujęcie prawdy Pisma św. ma ważkie następstwa także dla reinterpretacji dogmatów. Dobrze jest potraktować je łącznie z kryteriami poprawnego odczytywania myśli hagiografów, podanymi przez Konstytucję. W jej § 12 czytamy jako echo encykliki „Divino afflante Spiritu" następującą zasadę: ,celem odszukania intencji hagiografów należy między innymi uwzględnić również rodzaje literackie" (KO 12, 21n) Jednakże widzimy tu krok naprzód w porównaniu $\mathrm{z}$ encykliką: to kryterium już nie ma służyć samej obronie wolności Pisma św. od błędu (inerrantia), lecz ma służyć, jak wskazuje kontekst Konstytucji, nawskroś teologicznemu celowi szukania prawdy objawionej poprzez ludzkie uwarunkowanie narzędzi Ducha Świętego. Znamienny dodatek inter alia uprawnia egzegetów do posługiwania się wszelkimi innymi metodami hi-

6 ,...ce n'est pas la vérité au sens grec, la vérité historique en tant que telle; il s'agit de la vèrité au sens de la Bible et de la Tradition, c-à-d du contenu de la divine révélation. La véritè de l'Écriture que garantit l'inspiration, c'est donc "cette vérité de la révélation qui se rapporte toujours de quelque manière au salut des hommes". I. De La Potterie, La vérité de la S. Écriture et l'Histoire du salut d'après la Constitution dogmatique „Dei Verbum”, NRTh, 88 (1966) 165.

7 Por. L. Alonso Schökel, La parola ispirata, dz. cyt., 283-285. Tymczasem tak zastarzałe są pewne nawyki nomenklatury,że terminu ,bezbłędność" używają nawet zasłużeni komentatorzy dokumentów soborowych, np. U. Betti, La costituzione dogmatica sulla Divina Rivelazione, Torino 1967, 240-242.

8 Np. O. Loretz, Die Wahrheit der Bibel, Freiburg i/Br 1964; P. Grelot, La Bible Parole de Dieu, Paris 1965. 
storycznymi i krytycznymi, byleby ów sensus divinus był odkryty ${ }^{9}$. Teksty historyczne są „różnego typu” (KO 12, 23), stąd konieczne są takie metody, jak historia tradycji czy historia wątków tematycznych, które oświetlają już w Piśmie św. widoczne fazy rozumienia Objawienia Bożego w ciągu wieków. Zwolna ona powstaje w ciągu stuleci, a przecież ma wciąż jako głównego autora Ducha Swięteg.

Jako wyraźnie teologiczne zasady hermeneutyki biblijnej figurują w Konstytucji trzy: treściowa jedność Pisma św. (contentum et unitas), uwzględnienie Tradycji i analogia wiary. Skoro Sobór tę jedność umieszcza po uzasadnieniu najbardziej naukowych metod badania ludzkich uwarunkowań pisarzy świętych, znaczy to, że optymistycznie widzi możliwość harmonijnego połączenia ostatnich zdobyczy egzegezy z odnajdy-waniem „Bożego sensu” w Piśmie św. Wprost jak zachęta brzmi soborowe określenie zadania egzegetów: ,,pracować wedle tych zasad nad głębszym zrozumieniem i wyjaśnieniem sensu Pisma św., aby dzięki badaniu przygotowawczemu sąd Kościoła nabywał dojrzałości” (KO 12, 36). Mowa tu o sądzie Kościoła, który według dalszych słów dokumentu: „ma od Boga polecenie i posłannictwo strzeżenia i wyjaśniania (interpretandi) słowa Bożego" ( $\mathrm{KO} 28,38$ ). A zarazem pamiętamy z $§ 10$ kończącego rozdział o przekazywaniu słowa Bożego, że „Urząd ten Nauczycielski nie jest ponad słowem Bożym, lecz jemu służy" (KO 10, 59n). Nabywanie więc dojrzałości sądu przez Kościół w zakresie rozumienia Pisma św. należy do koniecznych procesów rozwojowych samego Kościoła. W sposób bardzo znamienny dokonuje się tu synteza zasad hermeneutyki biblijnej, ogólnej metodologii dyscyplin teologicznych i owej zbiorowej w Kościele cogitatio fidei. Cel zaś tej syntezy jest jeden — pełniejsze ujęcie i przyswojenia sobie rzeczywistości objawienia.

W rozdziale IV Konstytucji o Starym Testamencie zasługuje na uwagę - co powszechnie się podkreśla - brak rozstrzygnięcia wciąż aktualnych debat nad sensus plenior ST. Potwierdza to "Relatio" do § 12: „Abstrahitur autem a solvenda quaestione de sensu pleniore”. Wolno więc tutaj wysnuć argument ex silentiø: sprawa ta pozostaje do dalszego wyjaśnienia czyli nowe ,zielone światło" dla badań, których wyniki maja. znaczenie wyłącznie teologiczne. Natomiast inną pokrewną, choć nieco różną zasadę teologiczną podała nam Konstytucja. Jest nią adagium. św. Augustyna, zwane w żargonie biblistów latet - patet: „Bóg, sprawca natchnienia i autor ksiąg obydwu Testamentów mądrze postanowił, by Nowy Testament był ukryty w Starym, a Stary w Nowym znalazł wyjaśnienie" (KO 16, 25n). Zasada ta nie tylko jest potwierdzeniem typologii Ojców Kościoła, ale i wielu wątków tematycznych NT na kartach

\footnotetext{
9 Por. A. Grillmeier, LThK. Das II Vat. Konzil, dz. cyt., 2, 554.
} 
ST. Prowadzi ona do odnalezienia znacznie większej głębi nawet w tekstach, które uważa się powszechnie za bardzo zrozumiałe i już wszechstronnie wykorzystane. Tak np. w opisie kuszenia Jezusa słowa „Nie samym chlebem żyje człowiek, lecz lecz każdym słowem, które pochodzi z ust Bożych" (Mt 4, 23) po uwzględnieniu ich sensu, jaki mają w Pwt 8, 3, pozwalają nam dostrzec $\mathrm{w}$ kuszonym Jezusie doskonały antytyp Izraela $z$ jego pokusami na pustyni podczas wędrówki do Ziemi Obiecanej. Wykrycie tego związku ma kapitalne znaczenie dla rozumienia całości dziejów zbawienia.

Rozdział V o Nowym Testamencie miał bogatą historię, zanim otrzymał dzisiejszą formę. Nas tutaj interesuje już tekst ostateczny, i to tylko w punktach, które otwieraja pole dla nowych badań: W § 19 przy mocnym zaakcentowaniu stałej w Kościele wiary w historyczność Ewangelii pojawia się po raz pierwszy w dokumentach Kościoła lekko wycieniowana rola Ewangelistów jako redaktorów przekazu apostolskiego, przy czym dokument powołuje się na wydaną wówczas Instrukcję w tej sprawie Papieskiej Komisji Biblijnej ${ }^{10}$. „Apostołowie już po wniebowstąpieniu Pana to, co On powiedział i czynił, przekazali słuchaczom w pełniejszym zrozumieniu (pleniore intelligentia), którym cieszyli się pouczeni chwalebnymi wydarzeniami życia Chrystusa oraz światłem Ducha prawdy oświeceni. Swięci zaś autorowie napisali cztery Ewangelie, wybierając niektóre z wielu wiadomości przekazanych ustnie lub pisemnie; ujmując pewne rzeczy syntetycznie lub objaśniając, przy uwzglęủnieniu sytuacji Kościołów, zachowując wreszcie formę przepowiadania” (KO 19, 27-32). Potrójne Sitz im Leben, tzn. w życiu Jezusa, Kościoła i układzie Ewangelisty, wyraźnie podane we wspomnianej Instrukcji doszło i tutaj do głosu. A zatem kierunki Traditions - i Redaktionsgeschichte, $\mathrm{z}$ tym, co w nich jest twórcze, otrzymały prawo obywatelstwa w badaniach nad sensem przekazu. Powołanie się przy tym na wpływ faktów paschalnych i misję Ducha Swiętego nadaje ustnej tradycji ewangelijnej jej pełny wymiar teologiczny. Subtelna różnica między terminami ,apostoli" i ,auctores sacri” wraz z pominięciem w tym miejscu proponowanych pierwotnie imion czterech ewangelistów wskazuje na to, że badania nad autentycznością literacką Ewangelii stoją otworem. Wazniejsze są jednak tu dla nas implikacje teologiczne. Powyższe dwa zdania Konstytucji o przekazie apostolskim wzbogaconym o tyle czynników modyfikujących pierwotne przeżycia i o kunsztownym zapisie ewangelistów potwierdzają to, co już na dwa lata przed soborem lapidarnie ujął jeden z czołowych biblistów Soboru R. Schnackenburg: „Teologia nie zaczyna się dopiero z chwilą, gdy zaczęto objaśniać i systematyzować

10 Instructio ,Sancta Mater Ecclesia" a Pontificio Consilio Studiis Biblicis provehendis edita - $\mathrm{z}$ dnia 14. 5. 1964: AAS 56 (1964) 712-718. 
Objawienie przy pomocy filozofii greckiej, ona jest już w samej Biblii" ${ }^{11}$. To ujęcie ma doniosłe znaczenie przy korzystaniu ze słów NT w roli locus theologicus dla tez dogmatycznych. Teksty NT przy całej ich historycznej wierności co do istoty, nie są zapisem taśmy magnetofonowej, a docieranie do ipsissima vox Iesu jest w poszczególnych tekstach wciąż otwartym problemem dla egzegetów, żeby tylko przykładowo wyliczyć tekst „Ojcze nasz” lub formę konsekracji eucharystycznej, różnie referowane w różnych Ewangeliach. Teolog zatem przed wyzyskaniem siły dowodowej tekstu musi wziąc pod uwagę dające się ustalić świadome zamiary apostołów i redaktorów Ewangelii, gdyż i na nie rozciąga się wpływ Ducha Swiętego. Najbardziej tu godne podziwu jest śmiałe połączenie wyników szkół bardzo krytycznych w jedną konstruktywną całość z regułami teologicznymi śledzącymi myśl Bożą.

Wreszcie w ostatnim swym rozdziale Konstytucja podaje nowy obraz teologii. Nie jest to budowla raz na zawsze wzniesiona. Raczej wznosi się ona stale trzymając się swego fundamentu, jakim jest Pismo św. wraz z Tradycją. Nie tylko stoi ona na tym fundamencie, lecz nadto dzięki niemu stale się odmładza (KO 24, 38).

Kończąc ten przegląd nowych i odnawiających teologię sformułowań Konstytucji „Dei Verbum” jasno widzimy, że postulatowi odmłodzenia teologii, jakim jest nowa interpretacja dogmatów, ma zadość uczynić na pierwszym miejscu biblijne, oparte na nowych metodach ressourcement. Postęp biblistyki musi się odbić na reinterpretacji. Jak to należy rozumieć? Zgoda niemal powszechna panuje co do tego, że nowa teologia musi wychodzić z kategorii biblijnych i karmić się rozważaniem zbawczego planu ${ }^{12}$. Z drugiej jednak strony ubiblijnienie teologii nie oznacza bynajmniej zastąpienia scholastyki teologią biblijną. Nie jest to ani potrzebne ani wykonalne, bo teologia biblijna nie jest jeszcze do końca gotowa. Nie chodzi też o mówienie w teologii samym językiem biblijnym. Tego nie robią nawet bibliści przedstawiając doktrynę Pisma św. Wystarczy tylko przypatrzeć się dziełu tak wartościowemu jak np. ,Theologisches Wörterbuch zum NT" R. Kittela i plejady współpracowników, by stwierdzić, jak w nim typowo niemiecki system pojęciowy służy sformułowaniom nauki NT. Chodzi więc o stały nawrót do formuł biblijnych, w których się odkrywa nową bazę treściową ożywiającą teologię ${ }^{13}$. W następnej zaś fazie chodzi o to, by słownictwo biblijne oddać językiem czasów dzisiejszych i przez to ożywić wykład prawd dotąd nieco stereotypowy. Do tego zaś trzeba śledzić ducha tak całego Pisma św.,

\footnotetext{
11 La théologie du Nouveau Testament. Etat de question. Bruges 1961, 13.

12 Por. J.-M. González Ruiz, Der Gebrauch der Bibel in der Kirche des Konzils, w: Die Autorität und Freiheit, München 1967, 1, 235.

13 Por. L. Alonso Schökel, La parola ispirata, dz. cyt., 154.
} 
jak i jego poszczególnych ksiąg, a te odkrycia stopniowo wprowadzać do teologii jako czynnik ją odmładzający ${ }^{14}$.

Tak pojęty proces odnowy będzie dalszym ciągiem tej teologii, jakiej zaczątki widać już na kartach Pisma św. Za J. Ratzingerem można wyróżnić takie jakby kolejne fale opracowań teologicznych całego Pisma Św.: 1. starotestamentalna teologia ST - tu historycy wpierw wyróżniają warstwy doktrynalne $\mathrm{w}$ ich rozwoju, 2. nowotestamentalna teologia ST - jest wynik owej relecture, której dokonali apostołowie i ewangeliści oraz pozostali pisarze NT w świetle życia Chrystusowego, 3. nowotestamentalna teologia NT - w niej znów fachowcy rozróżniają kolejne warstwy rozwoju doktryny w II połowie I wieku po Chrystusie, 4. kościelna teologia NT - już powiększona o Tradycję powstaje na końcu ${ }^{15}$. W ten sposób niejako organicznie ma przechodzić ożywczy prąd z Pisma św. do teologii.

\section{PRZYKEADY}

Wyśledźmy teraz, jakie spośród zdobyczy współczesnej biblistyki mogą w duchu wskazań soborowych dodatnio wpłynąć na nową interpretację dogmatów. Innymi słowy - jaka nowa baza treściowa w Piśmie św. wymaga uwzględnienia.

Ogólnie zarysowują się następujące typy reinterpretacji. W zakresie dogmatów w sensie ścisłym można mówić co najwyżej o wzbogaceniu aspektów, przesunięciu akcentu na inny składnik sformułowania lub o odkryciu nowych powiązań między prawdami. W zakresie zaś tez o niższej kwalifikacji niż dogmat możliwe są pewne poprawki, uściślenia i uzupełnienia. W obydwu zaś zakresach należy oczekiwać od biblijnego ressourcement przedłożenia nowych tematów do opracowania.

Zacznijmy od wyników egzegezy, szczegółowej. Uwzględnienie rodzajów literackich pierwszych trzech rozdziałów Księgi Rodzaju, liczenie się przy tym z ową synkatábasis słowa Bożego do ludzkiego poziomu ekspresji w epoce tak zamierzchłej i w środowisku kulturowym tak różnym od naszego nakazuje rewizję wielu zastanych poglądów. Hexaemeron staje dziś w innym świetle, podobnie jak rajski upadek z jego następstwami. Osobny referat poświęcony temu tematowi zwalnia nas tu od rozwodzenia się nad nim. Warto tylko podkreślić tu zmianę aury, $\mathrm{w}$ jakiej powstawały prace biblistów dzisiejszych na ten temat. Tacy uczeni, jak P. Grelot czy L. Ligier, nie są bynajmniej apologetami historyczności w dawnym ujęciu, lecz teologami. A dają swoją zupełnie

14 Por. O. Müller, Katholische Theologie nach dem Konzil, w: Die Autorität und Freiheit, dz. cyt., 1, 94.

15 Por. J. Ratzinger, Offenbarung und Überlieferung, Wien 1965, 42-44. 
świeżą syntezę doktrynalną wykorzystując tak nowsze badania naukowe jak wyniki dyscyplin świeckich. Uogólniając temat - w antropologii biblijnej, która bardzo późno przejęła język platońskiego dualizmu, zwraca się uwagę coraz bardziej na jednolitą, choć nie monistyczną, koncepcję człowieka.

W doktrynie trynitarnej egzegeta katolicki lat temu juz trzydzieści zakwestionował adagium teologiczne,,omnia opera od extra sunt communia tribus Personis S. Trinitatis". Dokonał zaś tego w imię osiągnięć egzegezy szczegółowej, zwracając uwagę na subtelne różnice w stosowaniu greckich przyimków ek, dià, en w tekstach mówiących o nadprzyrodzonym działaniu Ojca, Syna i Ducha Swiętego na wiernych. Tu chodzi o coś więcej niż dotychczasowe apropriacje ${ }^{16}$. Zbędne jest podkreślać, jak dalece specyfikacja działań Trzech Osób harmonizuje z dynamiką zbawczego planu i biblijnym obrazem Trójcy.

W chrystologii formuła chalcedońska $\mathrm{z}$ jej następstwami chyba mogłaby być uzupełniona, a w szczegółach zmodyfikowana przez dane biblijne. Chodzi o następstwa Wcielenia. Np. tekst o dniu paruzji: „O dniu owym lub godzinie nikt nie wie: ani aniołowie w niebie, ani Syn, tylko Ojciec" (Mk 13, 31 par.) kazał niektórym biblistom postawić pod znakiem zapytania tezę głoszącą: Dusza ludzka Chrystusa posiadała od pierwszej chwili swego istnienia uszczęśliwiające widzenie Boga i w Bogu widziała wszystko, co dotyczy jej stanu" ${ }^{17}$. To, co określa się dziś jako postulat zjednoczenia osobowego, nie było konieczne w oczach takiego bojownika unii hipostatycznej, jakim był św. Cyryl Aleksandryjski. Nie widział on trudności w przyjęciu zdania, że Logos przez Wcielenie posunął się do przyjęcia wszystkiego, co należy do naszej natury, włącznie z niewiedzą ${ }^{18}$. Modyfikacja tego zapatrywania mogłaby uprościć inne kwestie

16 Por. G. Thils, L'Enseignement de saint Pierre (Études bibliques), Paris 1943, $64-67$.

17 Kwalifikację teologiczną powyższej tezy niejednakowo podają współczesne podręczniki. I tak "ogólna nauka teologów” podaje W. Granat, Chrystus Bóg-Człowiek (Dogmatyka katolicka III), Lublin 1969, 293, przy czym nie ma tam wzmianki o trudności, jaką nastręcza dla tezy tekst cytowany o dniu paruzji. Natomiast F. Dziasek, Jezus Chrystus Boski Posłaniec, Poznań 1963, 289, 328 podając kwalifikację „,doktryna teologicznie pewna", omawia trzy znane w tradycji interpretacje wspomnianego tekstu opowiadając się za tą, którą dał św. Grzegorz w liście do Eulogiusza (DBU 248). Tezę tę uzasadniał także św. Tomasz z Akwinu powołując się na dwa teksty, z których właściwie żaden nie jest ściśle chrystologiczny ani Ps 64,5 ani J 3, 34. por. S. Th III, q. 34, a. 4. Tezę de scientia beata (lub: visione beata) in anima Christi uznać za teologicznie pewną według kryteriów stosowanych przez dogmatykę nakazują nast. dokumenty: Dekret Sw. Oficjum z dnia 5.6.1918 (DBU 2183nn) oraz stwierdzenie jej przez Enc. Piusa XII „Mystici Corporis Christi” z dnia 29.6.1943 (AAS 35 [1943] 230). Tenże papież w Enc. „Humani generis” tezy teologiczne pewne spod swobodnej dyskusji teologów usunął, o ile się znalazły w encyklikach, jako rozstrzygnięcie kontrowersji (AAS 42 [1950] 568). Jeśli katoliccy bibliści mimo to zajęli się tą tezą w sensie reinterpretacji, a magisterium Kościoła na to nie zareagowało, wolno stąd wnosić, że owym restrykcjom ona nie podlega.

18 Thesaurus de sancta et consubstantiali Trinitate, ass. 22: PL 75, 369. Wstęp 
z zakresu chrystologii, jak np. posiadanie przez Jezusa cnót wiary i nadziei a także sprawę odczuwalności męki, poczynając od agonii w Getsemani ${ }^{19}$.

Przejdźmy do osiągnięć teologii biblijnej. Jej, jak wiadomo, zawdzięcza się wypracowaną na podstawie kategorii biblijnych, zwłaszcza Pawłowego pojęcia oikonomía, tak płodną na ostatnim soborze ideę zbawczego Planu Boga. Ta idea ma być, jak chce sobór, osią struktury tak teologii, jak jej przekazywania w duszpasterstwie. Różne możliwości jej zastosowania jako podstawowej struktury sprawią na przyszłość, że podręczniki teologii nie będą już — jak dowcipnie określono - podobne do siebie jak jajko do jajka (O. Müller).

Najbardziej chyba płodny i odnawiający jest wkład teologii biblijnej do soteriologii. Tu trzeba wspomnieć takie tematy, jak odwieczność zbawczego planu na podstawie Ef 1, 4-14, który to tekst wielokrotnie pojawia się $\mathrm{w}$ dokumentach soborowych Vaticanum II, Pawłową typologię Adam - Chrystus z Rz 5 i 1 Kor 15 o reperkusjach także eklezjologicznych w Ef 5, 23-32, w znanym tekście o wielkiej tajemnicy, gdzie poszerza się typologia Adam - Chrystus o drugą: Ewa - Kościól. Dotąd w tradycyjnej dogmatyce nie była dowartościowana zbawcza doniosłość zmartwychwstania Chrystusa, którą na gruncie teologii biblijnej spopularyzowało cenne studium F. X. Durrwella ${ }^{20}$. Odrębny referat o zmartwychwstaniu zwalnia nas tu od dalszych wywodów. Przechodząc zaś do szczegółowych tematów soteriologii czeka na opracowanie doniosłość męki Chrystusa jako antytypu konkretnych ofiar ST, na co naprowadza szereg prac biblistów 21. Do niedawna podręczniki teologii dogmatycznej nie poruszały w ramach swej soteriologii zagadnienia odkupienia kosmicznego, mimo że tyle na nie jest danych w NT, zwłaszcza u św. Pawła, i mimo że temat ten znali od dawna Ojcowie Kościoła i lex orandi - liturgia. Temat ten jest na styku $z$ eschatologią, mianowicie z biblijnym pojęciem ,nowego nieba i nowej ziemi” (Iz 65, 17; 66,22 ; Ap 21, 1. 5). Inny i nieoczekiwany styk soteriologii $z$ angelologią ukazuje się w temacie triumfu Chrystusa nad „Potęgami” ducho-

do cytowanego miejsca por. RJ 2072. Powyższy tekst św. Cyryla jako argument przeciw tezie podaje magistralny artykul R. E. Brown, How Much Did Jesus Know?, CBQ, 29 (1967) 315-345.

${ }_{19}$ Co do wiary - por. S. Th. III, q. 7, a. 3, co zaś do połączenia wizji uszczęśliwiającej z męką odczuwalną - por. STh III, q. 46, a. 7 i 8. Dogmatyczne trudności omawia F. Dziasek, Jezus Chrystus..., dz. cyt., 1, 282. 297-299.

${ }_{20}$ La Résurrection de Jésus mystère du salut. Étude biblique, Le Puy - Paris ${ }^{4}$ 1954; niemiecka wersja: Die Auferstehung Christi als Heilsmysterium, Salzburg 1958.

21 Por. E. E. May, Ecce Agnus Dei, Washington 1947; L. Moraldi, Espiazione sacrificale e riti espiatori nell'ambiente biblico e nell' Antico Testamento (Analecta biblica 5), Roma 1956; L. Ligier, Péché d'Adam et Péché du monde (Théologie 43. 48), Paris 1960/61, 2tt; L. Sabourin, Rédemption sacrificielle, Bruges 1961; H. Strąkowski, Chrystus Baranek Boży w Piśmie św., Lublin 1961; N. Füglister, Die Heilsbedeutung des Pascha (Studien zum A. und NT 8), München 1963. 
wymi. Zagadnienie to jeszcze nie doczekało się na gruncie teologii biblijnej rozwiązania powszechnie uznanego. Niemniej zdaje się ono zapowiadać poszerzenie, i to znaczne dotychczasowej angelologii. Jeśli bowiem okaże się na podstawie tekstów Pawłowych, że niektóre z "Potęg” są jeszcze faktycznie neutralne wobec Chrystusa, wówczas możliwa będzie hipoteza, że wciąż trwa jeszcze stwarzanie duchów i poddawanie ich próbie właśnie chrystocentrycznej.

W zakresie sakramentologii należy oczekiwać bardziej biblijnego ujecia znaku jako ,przedłużenia zbawczych czynów Chrystusa” (A. Feuillet) na zasadzie powiązania z szerzej ujętą erą mesjańską, a więc i z eschatologią, wreszcie uwypuklenia dynamiki działania w nich Ducha Swiętega ${ }^{22}$. Wzięcie pod uwagę powyższych aspektów biblijnych może oddać sakramentologii większe usługi niż upatrywanie w każdym sakramencie składników materii i formy, choć oczywiście w niektórych z nich traf-ność zastosowania tego podziału jest uderzająca. W zakresie sakramentów najbogaciej udokumentowanych w NT, a więc chrztu i Eucharystii, odnowa będzie następstwem większego niż dotąd uwzględnienia ich typologii biblijnej, wszystkich implikacji paschalnych, które w szeregu swych prac wydobył na jaw $\bar{H}$. Schürmann ${ }^{23}$, wreszcie aspektu eschatologicznego.

W końcu - last not least - eschatologia, istne w teologii NT ,,gorące żelazo" (R. Schnackenburg), przedmiot nieustannych kontrowersji, mimo wszystkich trudności zapowiada bardzo wiele nowych elementów twórczych. Czeka tu na wypracowanie jej koncepcja bardziej zwarta, tzn. by między eschatologią indywidualną, głównie dotąd opracowywaną, a powszechną skąpiej uwzględnianą w trakcie nie było dotychczasowego przedziału. Czynnikiem jednoczącym będzie opracowanie szerzej pojęcia paruzji Chrystusa z jej rozciągnięciem na śmierć chrześcijanina. Taż właśnie śmierć z kolei, w której teologii znalazł K. Rahner tyle zagadnień niedopracowanych ${ }^{24}$, zyska wiele na potraktowaniu jej bardziej chrystocentrycznie i łącznie ze zmartwychwstaniem. Narzuca się nowe na podstawie zwłaszcza IV Ewangelii potraktowanie sądu, tak by oba sądy szczegółowy i powszechny miały wspólny mianownik odniesienia do Chrystusa wciąż wybieranego albo odrzucanego przez pasmo wolnych decyzji człowieka.

22 Por. mój artykuł: O biblijnych kategoriach sakramentologii, AtKapł, 67 (1964) $269-276$.

${ }_{23}^{2}$ Lk 22, 19b-20 als ursprüngliche Textüberlieferung, Bib, 32 (1951) 364-392. 522-541, powtórzono w dziele tegoż autora: Traditionsgeschichtliche Untersuchungen $z u$ den synoptischen Evangelien, Düsseldorf 1968, 159-192; Tenże, Der Paschamahlbericht Lk 22, (7-14) 15-18 (NTA 19-5), Münster 21968; Tenże, Jesu Abendmahlshandlung als Zeichen für die Welt, Leipzig 1970. ${ }^{4} 1963$.

${ }_{24}$ Zur Theologie des Todes (Quaestiones disputatae 2), Freiburg - Basel - Wien 
Tyle tytułem prostego wyliczenie niektórych spraw aktualnych z zakresu biblijnego ressourcement.

Jeszcze do niedawna często się mówiło o nieuniknionych napięciach i konfliktach między biblistami a dogmatykami czy w ogóle teologami systematycznymi. Tymczasem jak być powinno odtąd naprawdę? Omówione tu przez nas wytyczne Konstytucji „Dei Verbum” tak ustawiaja tę sprawę, że przynajmniej de iure konflikt ten powinien coraz bardziej maleć. Ufajmy, że bibliści będą mogli wnieść swój wkład niezbędny do nowej interpretacji dogmatów i tez dogmatyki bez przeszkód ze strony specjalistów. 